\title{
Inhibition Effect of Zirconium Coating on Calcium Phosphate Precipitation of Titanium to Avoid Assimilation with Bone
}

\author{
Equo Kobayashi ${ }^{1}$, Miyuki Ando ${ }^{1, *}$, Yusuke Tsutsumi ${ }^{1}$, Hisashi Doi ${ }^{1}$, \\ Takayuki Yoneyama ${ }^{1}$, Masahiro Kobayashi ${ }^{2}$ and Takao Hanawa ${ }^{1}$ \\ ${ }^{1}$ Institute of Biomaterials and Bioengineering, Tokyo Medical and Dental University, Tokyo 101-0062, Japan \\ ${ }^{2}$ Department of Life and Environment Sciences, Chiba Institute of Technology, Narashino 275-0016, Japan
}

In order to control of the calcium phosphate precipitation of Ti in body fluid, which might result in assimilated bone re-facture during removal operation of implanted devices such as femoral nails and bone screws after healing, vacuum vapor deposition of $\mathrm{Zr}$ on $\mathrm{Ti}$ Substrate was carried out. The calcium phosphate precipitation was evaluated through the immersion test into the Hanks' solution. Scanning electron microscopy (SEM) and X-ray photoelectron spectroscopy (XPS) were conducted to evaluate inhibition effect of coated Zr layer.

Calcium phosphate particle were observed on the Ti with and without $90-\mathrm{nm}$ thick $\mathrm{Zr}$ coated layer by SEM. On the other hand, on the specimens with 130-nm thick Zr coated layer and those of $\mathrm{Zr}$ sputter-coated, no calcium phosphate particle was observed. By the surface analysis of the specimens $\mathrm{Zr}$ sputter-coated, Ca was not identified. It was considered to form zirconium phosphate instead of calcium phosphate by immersion in the Hanks' solution. It was suggested that Zr coating technique can be applied to orthopedic devices to avoid re-fracture of bone by calcium phosphate precipitation during removal operation. [doi:10.2320/matertrans.48.301]

(Received September 27, 2006; Accepted December 18, 2006; Published February 25, 2007)

Keywords: biomedical titanium alloys, zirconium coating, surface modification, calcium phosphate, biocompatibility

\section{Introduction}

Due to its less toxicity and superior biocompatibility, Ti and its alloys are used as biomaterials widely in the field of orthopedics. It is well known that $\mathrm{Ti}$ is thermodynamically active against to maintain a stable passive oxide film. This passive film acts as a protective film for corrosion. In a macroscopic view, the film is stable, namely inactive. However the partial dissolution and precipitation are repeated constantly in a microscopic view. ${ }^{1)}$ Therefore, when Ti is implanted in living body, the composition of the oxide film is gradually changed by influence of the environment during repeated dissolution and precipitation. Elements contained in body fluid, such as $\mathrm{P}, \mathrm{Ca}$ and $\mathrm{S}$ are involved in oxide film. Then calcium phosphate is formed on the surface of Ti. This phenomenon is confirmed both in vivo and in vitro. ${ }^{2-4)}$ In general, bone conductivity of a material could be evaluated with the formation of calcium phosphate on the material in a simulated body fluid.

For the fast fixation of artificial hip joints to hard tissue after surgical operation, the enhancement of this calcium phosphate precipitation is a key technology and several kinds of surface modification have been developed, such as electrolysis techniques, ${ }^{5,6)}$ immersion in alkaline solution, ${ }^{7)}$ immersion in hydrogen peroxide ${ }^{8)}$ hydro-thermal treatment ${ }^{9)}$ and calcium ion implantation ${ }^{10,11)}$ to modify the surface inducing active interactions between the modified surface and hard tissue. Some of them have been already applied to the commercial artificial hip joints to shorten the fixation period.

However, for some kinds of internal fixation devices implanted into marrow, such as femoral, tibial and humeral nails and screws for bone plate fixation, titanium's property forming fastly calcium phosphate is not ideal. For these

*Undergraduate Student, Chiba Institute of Technology. Present address:

Sankosha Engineering, 988 Kanoyamachi, Hachioji 192-0815, Japan removal implant devices, assimilation with bone by the calcium phosphate precipitation might cause in re-fracture of the bone during removal operation. Thus, for the removal implant devices into marrow, the inhibition of the calcium phosphate precipitation is required. The requirement is completely opposite against the purpose of a large portion of surface treatments in Ti materials for the acceleration of bone formation.

Zirconium is known to have less toxicity and good corrosion resistance similar to $\mathrm{Ti}$. Ti-13Nb-13Zr alloy has been developed in early 1990s as a beta-type Ti orthopedic alloy. In the previous paper on alloys' surface analysis after immersion into Hanks' solution, an artificial body fluid simulating inorganic components of the extracellular body fluid, zirconium phosphate precipitation was observed on pure $\mathrm{Zr}$ and $\mathrm{Ti}-\mathrm{Zr}$ binary alloys containing more than $34.4 \mathrm{~mol}^{3)}$ instead of calcium phosphate precipitation seen, while calcium phosphate was precipitated on $\mathrm{Ti}$ and $\mathrm{Ti}$ $14.9 \mathrm{~mol} \% \mathrm{Zr}$ alloy. It was concluded that zirconium oxide didn't involve $\mathrm{Ca}$ ion during repeated dissolution and precipitation of oxide. In other words, $\mathrm{Zr}$ has an ability to prevent the precipitation of calcium phosphate.

In the present study, vacuum vapor deposition of $\mathrm{Zr}$ onto the Ti disk substrates was carried out in order to control of the calcium phosphate precipitation of Ti. The calcium phosphate precipitation was evaluated through the immersion test into the Hanks' solution, followed by scanning electron microscopy, SEM, and X-ray photoelectron spectroscopy, XPS.

\section{Experimental}

\subsection{Specimens}

Disks of Ti (10 mm in diameter and $1.5 \mathrm{~mm}$ in thickness) were cut out from pure Ti rods ( 99.9 mass $\%$ in purity, Nilaco) by an abrasive wheel cutter. Top surface for $\mathrm{Zr}$ deposition was mirror-polished with diamond paste $(9 \mu \mathrm{m})$ and alumina 
Table 1 Ion concentration of Hanks' solution.

\begin{tabular}{ccccccccc}
\hline Ion & $\mathrm{Na}^{+}$ & $\mathrm{K}^{+}$ & $\mathrm{Mg}^{+}$ & $\mathrm{Ca}^{+}$ & $\mathrm{Cl}^{-}$ & $\mathrm{HCO}_{3}{ }^{-}$ & $\mathrm{HPO}_{4}{ }^{2-}$ & $\mathrm{SO}_{4}{ }^{2-}$ \\
\hline $\begin{array}{c}\text { Concentration } \\
(\mathrm{mol} \%)\end{array}$ & 141.9 & 5.8 & 1.7 & 1.3 & 144.8 & 4.2 & 0.9 & 1.7 \\
\hline
\end{tabular}

paste $(0.05 \mu \mathrm{m})$. Bottom surface and round surfaces were finished with 320 grid SiC papers.

Vacuum vapor deposition of $\mathrm{Zr}$ onto the Ti disk substrates was carried out using a commercial vacuum evaporator (JEE420, JEOL) with $\mathrm{Zr}$ ingots on tungsten baskets. The basket ( $\mathrm{Zr}$ ingot) height was fixed $80.0 \mathrm{~mm}$ above of the Ti disks. Five or six disks were deposited same time of deposition. Zirconium ingots were made from sponge $\mathrm{Zr}$ (99.6 mass\% in purity, Toho Titanium) by argon arc melting on a waterchilled cupper hearth. Half-masked disks were used to measure $\mathrm{Zr}$ coated layer thickness. Coated layer thickness was measured using a laser profile microscope (VF-7500, Keyence) by step height of coated part and uncoated part of a specimen which was half-masked tightly with a small piece of thin paper.

Reference materials, such as $\mathrm{Ti}$ without $\mathrm{Zr}$ and sputtercoated $\mathrm{Zr}$ on Ti substrates (Hokuto Denko) were also tested. The thickness of the coated layer on the latter specimens was approximately $1 \mu \mathrm{m}$ which was measured by the crosssectional optical microscopy of a specimen. The surface of sputter-coated $\mathrm{Zr}$ showed slight roughness $\left(R_{a}=0.26 \mu \mathrm{m}\right)$.

\subsection{Immersion test in Hanks' solution}

The immersion test was conducted with Hanks' solution ( $\mathrm{pH} 7.4)$, an artificial body fluid simulating inorganic components of the extracellular body fluid, at $310 \mathrm{~K}$. The ion contents of Hanks' solution are shown in Table 1. Specimens were immersed into $50 \mathrm{~mL}$ of Hanks' solution in sealed containers made of polytetrafluoroethylene (PTFE) for $1 \mathrm{~d}$ (specimens for XPS) or $7 \mathrm{~d}$ (those for SEM). The PTFE containers were kept in an incubator to keep the temperature at $310 \mathrm{~K}$. For the immersion test for SEM, Hanks' solution was changed once in three days. The $\mathrm{pH}$ alteration during immersion tests was detected using a $\mathrm{pH}$ meter (HM-60V, DKK-Toa).

\subsection{Surface observation and analysis}

Surface observation was carried out with specimens after immersion test for $7 \mathrm{~d}$ with an SEM (JSM-6400, JEOL) at 7 to $15 \mathrm{kV}$ of acceleration voltage. Surface analysis for $1 \mathrm{~d}$ immersed specimens was conducted with an XPS (SSX-100, $\mathrm{SSI}$ ). An X-ray source was monochromatized $\mathrm{Al} \mathrm{K} \alpha$ $(1486.61 \mathrm{eV})$ accelerated with $15 \mathrm{kV}$. The photoelectrons were detected through $58.7 \mathrm{eV}$ in FAT pass energy, with $35^{\circ}$ of detection angle under a vacuum atmosphere at $10^{-7} \mathrm{~Pa}$ or less. Binding energies of photoelectrons were calibrated by binding energy peak of $\mathrm{C} 1 \mathrm{~s}$ (binding energy, $285.0 \mathrm{eV}$ ) originating from so-called contaminated carbon. The spectrometer was calibrated against $\mathrm{Au} \mathrm{4 \textrm {f } _ { 7 / 2 }}(84.07 \mathrm{eV})$ and $\mathrm{Au} 4 \mathrm{f}_{5 / 2}(87.74 \mathrm{eV})$ of pure gold and $\mathrm{Cu} 2 \mathrm{p}_{3 / 2}(932.53 \mathrm{eV})$, $\mathrm{Cu} 2 \mathrm{p}_{1 / 2}\left(952.35 \mathrm{eV}\right.$ ) and $\mathrm{Cu}$ Auger $\mathrm{L}_{3} \mathrm{M}_{4,5} \mathrm{M}_{4,5}$ line (kinetic energy, $918.65 \mathrm{eV}$ ) of pure cupper. The energy values were based on the published data. ${ }^{12)}$ Analysis was conducted at least two points of a specimen. The composition and

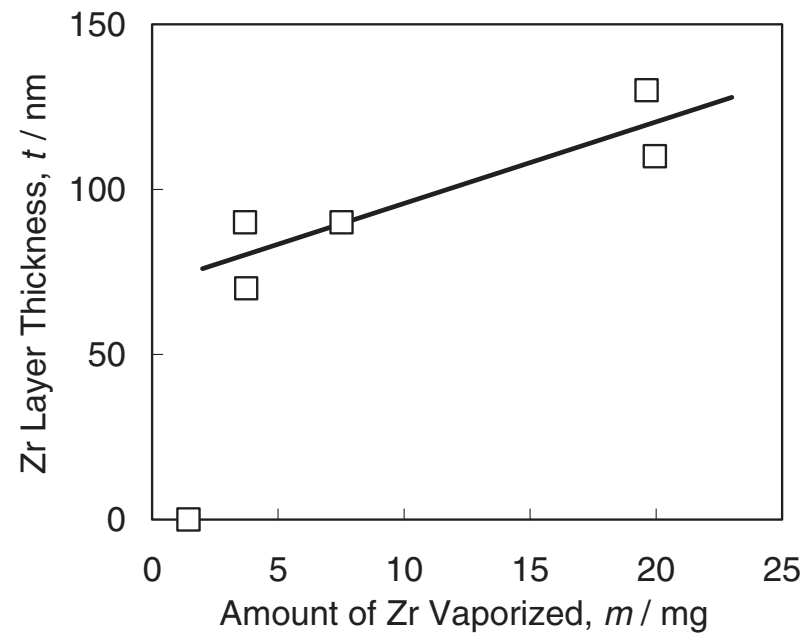

Fig. 1 Relation between amount of $\mathrm{Zr}$ vaporized and layer thickness after vapor deposition.

thickness were determined with an inductively calculating method presented by Asami et al. ${ }^{13)}$

\section{Results and Discussion}

\subsection{Thickness of $\mathrm{Zr}$ coated layer}

Mass loss of $\mathrm{Zr}$ ingot after each vacuum vapor deposition was varied from $3.69 \mathrm{mg}$ to $19.95 \mathrm{mg}$. Relation between mass loss and thickness of $\mathrm{Zr}$ coated layer measured by the laser profile microscope is shown in Fig. 1. It shows good liner relation at higher than $3.69 \mathrm{mg}$ vapor deposition. It is suggested that the thickness of $\mathrm{Zr}$ coated layer can be controlled by the vaporized amount of $\mathrm{Zr}$.

\subsection{SEM observation after immersion test}

Scanning electron micrographs of surface of Ti without $\mathrm{Zr}$ coating, Ti with $\mathrm{Zr}$ vapor deposited with coating thickness as $90 \mathrm{~nm}$ and $130 \mathrm{~nm}$, and Ti with $\mathrm{Zr}$ sputter-coated are shown in Fig. 2. On the surface of $\mathrm{Ti}$ without $\mathrm{Zr}$ coating, precipitates with $1 \mu \mathrm{m}$ in diameter are observed. In contrast, no precipitates were observed on $\mathrm{Ti}$ specimens with $\mathrm{Zr}$ vaporcoated layer. On the specimen with sputter-coated layer showed very small amount of precipitates. It is considered formed on the sputter-coated layer due to its rough surface.

\subsection{XPS surface analysis before and after immersion test}

Specimens immersed into the Hanks' solution for $1 \mathrm{~d}$ were used for the XPS analysis. Figure 3 shows the survey spectrum of the specimens (a) before and (b) after immersion. From the $\mathrm{Ti}$ without and with $\mathrm{Zr}$ vapor deposited $(90 \mathrm{~nm}$ thickness) after immersion into Hanks' solution, peaks corresponding to binding energy of $\mathrm{P} 2 \mathrm{p}$ clearly seen.

Figure 4 shows narrow area spectrum of $\mathrm{P}, \mathrm{Ca}, \mathrm{Ti}, \mathrm{Zr}$ and O. Examples of peak of $\mathrm{P}, \mathrm{Ca}, \mathrm{Ti}$ and $\mathrm{O}$ are taken from $\mathrm{Ti}$ without $\mathrm{Zr}$ coating after 1-d immersion in the Hanks' solution, while that of $\mathrm{Zr}$ from $\mathrm{Ti}$ with $\mathrm{Zr}$ vapor deposited with $130-n m$ coating thickness.

Spectra of P $2 \mathrm{p}$ was obtained as combined peak at around $134 \mathrm{eV}$. According to the previous report, $\mathrm{P} 2 \mathrm{p}$ binding 

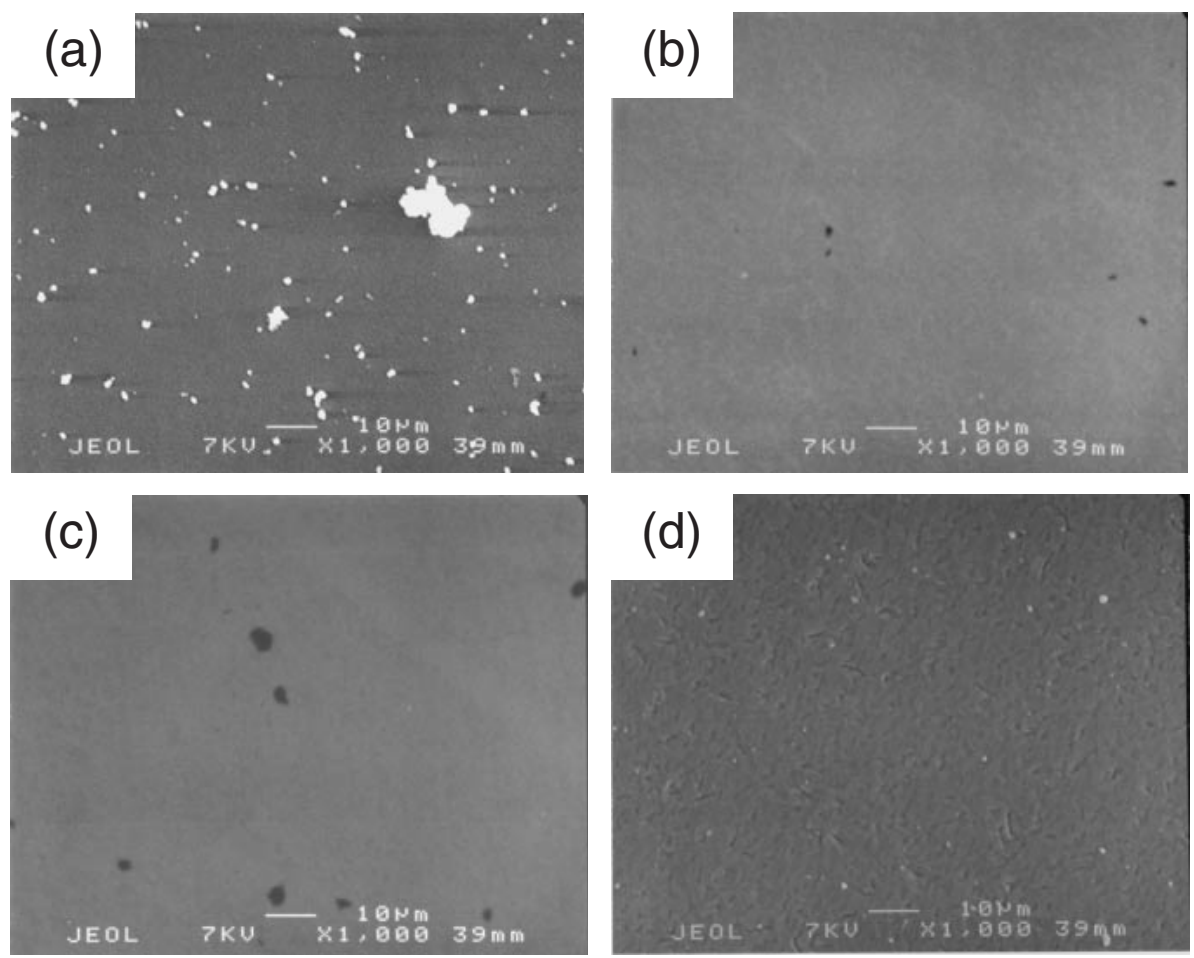

$30 u m$

Fig. 2 Specimens' surface after $7 \mathrm{~d}$ immersion into Hanks' solution at $310 \mathrm{~K}$, (a) Ti without $\mathrm{Zr}$ coating, (b) Ti with $\mathrm{Zr}$ vapor-coated $(90 \mathrm{~nm}),(\mathrm{c}) \mathrm{Ti}$ with $\mathrm{Zr}$ vapor-coated $(130 \mathrm{~nm})$, and (d) Ti with $\mathrm{Zr}$ Spatter-coated.
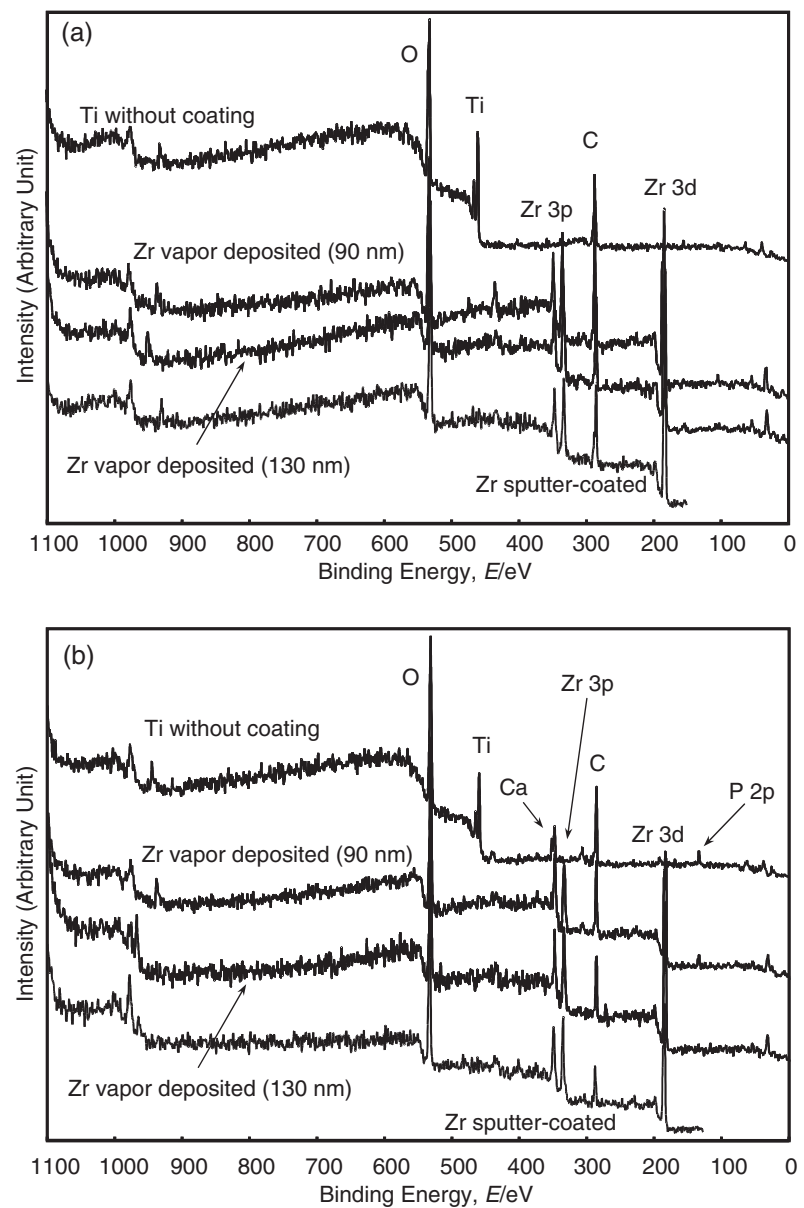

Fig. 3 Survey spectrum of specimens, (a) before and (b) after immersion into Hanks' solution for $1 \mathrm{~d}$. energies of potassium phosphates and sodium phosphates are varied from $132.7 \mathrm{eV}$ to $133.9 \mathrm{eV}$, while those of several calcium phosphates, such as $\mathrm{Ca}_{10}\left(\mathrm{PO}_{4}\right)(\mathrm{OH})_{2}, \mathrm{CaHPO}_{4} \cdot \mathrm{H}_{2} \mathrm{O}$ and $\mathrm{Ca}\left(\mathrm{H}_{2} \mathrm{PO}_{4}\right)_{2} \cdot \mathrm{H}_{2} \mathrm{O}$ are $133.2 \mathrm{eV}$ to $134.3 \mathrm{eV} .{ }^{2)}$ Although it was difficult to deconvolute the spectra of $\mathrm{P} 2 \mathrm{p}$ into $\mathrm{H}_{2} \mathrm{PO}_{4}{ }^{-}$, $\mathrm{HPO}_{4}{ }^{2-}$ and/or $\mathrm{PO}_{4}{ }^{3-}$ in the present study, the combined peak around $134 \mathrm{eV}$ shows good correspondence to $\mathrm{P} 2 \mathrm{p}$ binding energies of calcium phosphates in the previous report. Doublet peaks of $\mathrm{Ca} 2 \mathrm{p}$ was identified as $\mathrm{Ca} 2 \mathrm{p}_{1 / 2}$ and $\mathrm{Ca} 2 \mathrm{p}_{3 / 2}$ referring to previous report. ${ }^{2,3)}$

The peak of $\mathrm{Ti}$ was deconvoluted into $\mathrm{Ti}^{0}$ from metallic substrate and cations having different valence $\left(\mathrm{Ti}^{2+}, \mathrm{Ti}^{3+}\right.$, $\left.\mathrm{Ti}^{4+}\right)$. On the other hand, only tetra-valent oxide was detected for $\mathrm{Zr}$ in the present study. According to previous report, peak from $\mathrm{O} 1 \mathrm{~s}$ can be deconvoluted into $\mathrm{O}^{2-}, \mathrm{OH}^{-}$ and $\mathrm{H}_{2} \mathrm{O} .{ }^{13)}$ They correspond to binding energy of hydroxyl, bound water or adsorbed water in the oxide layer and oxygen consisting oxide, respectively. Because phosphate groups were detected in $\mathrm{Ti}$ without $\mathrm{Zr}$ coating specimen together with only cation $\mathrm{Ca}^{2+}$, the particles seen in SEM observation were concluded as calcium phosphates.

Quantitative analysis based on the peak deconvolution shown in Fig. 4 was carried out. Concentration of $\mathrm{P}$ and $\mathrm{Ca}$ taken from specimen after 1-d immersion in Hanks' solution is shown in Fig. 5. In the Ti without $\mathrm{Zr}$ coating and the 90-nm thick $\mathrm{Zr}$ deposited specimen, approximately $3 \mathrm{~mol} \%$ of $\mathrm{P}$ and Ca was detected, while $1.5 \mathrm{~mol} \%$ of $\mathrm{P}$ and no Ca was exist on the specimen the $90 \mathrm{~nm}$ thick $\mathrm{Zr}$ deposited and that $\mathrm{Zr}$ sputter-coated. It is considered that this difference was presumably caused from imperfection of coated layer.

The ratio, $[\mathrm{Ca}] /[\mathrm{P}]$, on the $\mathrm{Ti}$ without $\mathrm{Zr}$ specimen, 

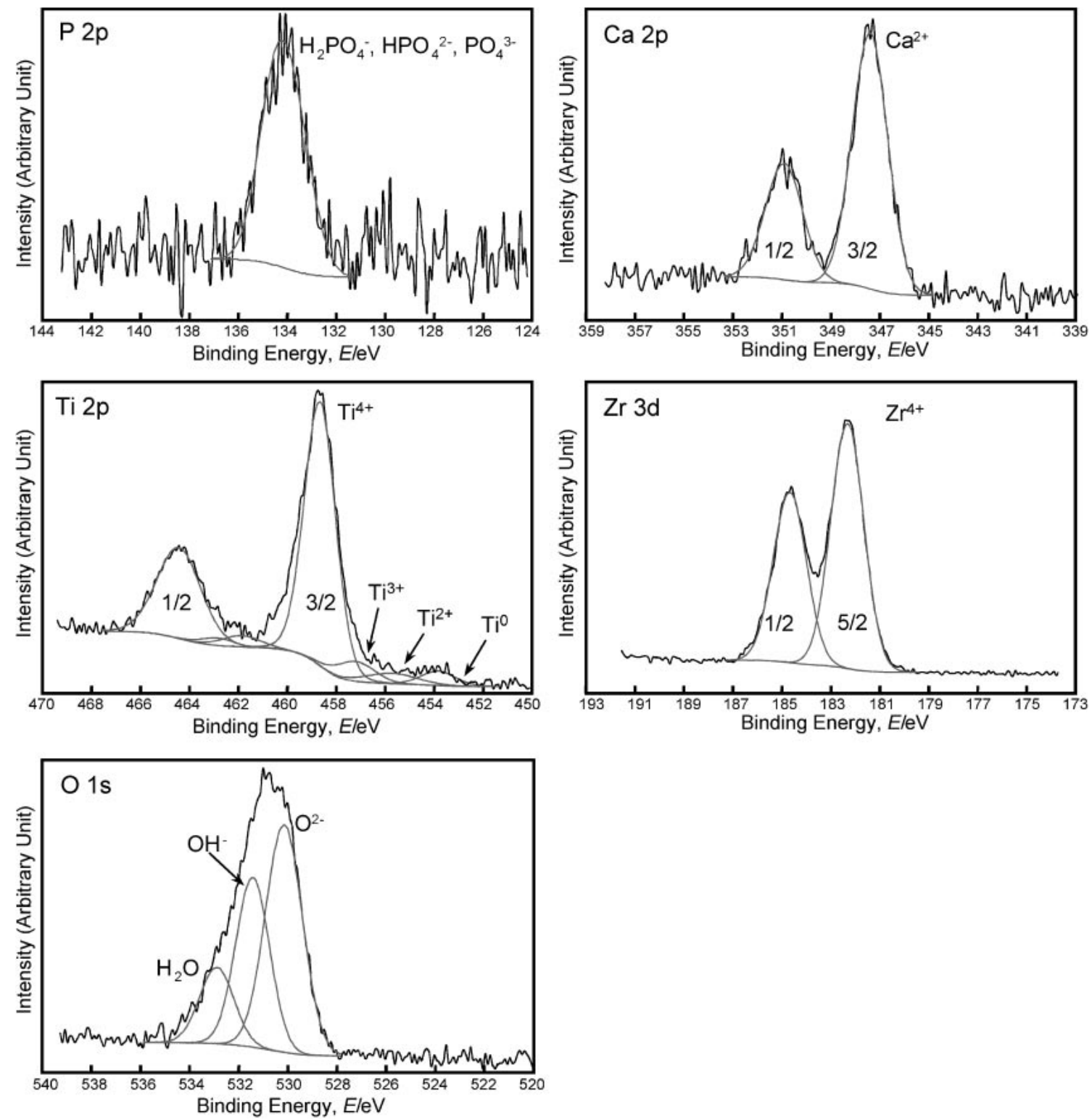

Fig. 4 Examples of peak deconvolution of narrow area spectrum of XPS analysis for P, Ca, Ti, Zr and O. All of the example spectrum are taken from specimen of $\mathrm{Ti}$ without $\mathrm{Zr}$ coating after immersion, except $\mathrm{Zr}$ spectra which is taken from that of Ti with $\mathrm{Zr}$ vapor deposited with $130-n m$ coating thickness.

calculated from above results was about 1.2. It is slightly smaller than that of hydroxyapatite $\left(\mathrm{Ca}_{10}\left(\mathrm{PO}_{4}\right)_{6}(\mathrm{OH})_{2}\right)$, which is known to 1.67 , and rather nearer to that of $\mathrm{Ca}_{8}\left(\mathrm{HPO}_{4}\right)_{2}\left(\mathrm{PO}_{4}\right)_{4}$, which is $1.33 .{ }^{3)}$

According to the previous report, zirconium phosphate was observed on the pure $\mathrm{Zr}$ (purity $>99.9 \%$ ) surface instead of calcium phosphate. ${ }^{14)}$ It is reported that phosphate ion adhesion was occurred by dehydration and oxidation as follows,

$$
\begin{aligned}
& \mathrm{Zr}(\mathrm{OH})^{3+}{ }_{(\text {ox })}+\mathrm{H}_{2} \mathrm{PO}_{4}{ }_{(\text {(aq) }} \Leftrightarrow \mathrm{Zr}^{4+}{ }_{(\text {ox })} \cdot \mathrm{HPO}_{4}{ }^{2-}{ }_{(\text {ads })}+\mathrm{H}_{2} \mathrm{O} \\
& \mathrm{Zr}^{4+}{ }_{(\text {ox }} \cdot \mathrm{HPO}_{4}{ }^{2-}{ }_{\text {(ads) }}+\mathrm{OH}^{-} \Leftrightarrow \mathrm{Zr}^{4+}{ }_{(\text {ox })} \cdot \mathrm{PO}_{4}{ }^{3-}{ }_{(\text {ads })}+\mathrm{H}_{2} \mathrm{O} \\
& \mathrm{Zr}(\mathrm{OH})^{3+}{ }_{(\text {ox })}+\mathrm{HPO}_{4}{ }^{2-}{ }_{\text {(aq) }} \Leftrightarrow \mathrm{Zr}^{4+}{ }_{(\text {ox })} \cdot \mathrm{PO}_{4}{ }^{3-}{ }_{\text {(ads) }}+\mathrm{H}_{2} \mathrm{O}
\end{aligned}
$$

Suffixes of ox, aq and ads correspond to ions in oxide, aqueous solution and adhesion respectively. After these reactions, these phosphate ions were involved in oxide layers as forms of $\mathrm{PO}_{4}{ }^{3-}, \mathrm{HPO}_{4}{ }^{2-}$ and $\mathrm{H}_{2} \mathrm{PO}_{4}{ }^{-}$. According to the report, on the Ti surface, the adhesion of phosphate ions and $\mathrm{Ca}$ ion occurs alternately resulting in calcium phosphate precipitation. On the other hand, on the $\mathrm{Zr}$ surface, $\mathrm{Ca}$ ion adhesion is obstructed due to an interaction between the oxide and $\mathrm{Ca}$ ion, zirconium phosphate can be precipitated. In the present study, spectra of $\mathrm{P}$ was observed on the $\mathrm{Zr}$ sputter-coated specimens, which are considered to maintain the most fixed $\mathrm{Zr}$ layers, no spectra of $\mathrm{Ca}$ was detected.

As shown in Fig. 5, approximately $80 \%$ of atoms were $\mathrm{O}$ in the general results of quantity analysis by XPS. Ratio of the $\mathrm{P}$ and $\mathrm{Ca}$ is already stated above. $\mathrm{N}, \mathrm{Na}$ and $\mathrm{Si}$ are considered as surface contamination.

According to the results of peak deconvolution of $\mathrm{O}$ spectra into $\mathrm{O}^{2-}, \mathrm{OH}^{-}$, and $\mathrm{H}_{2} \mathrm{O}$, which correspond to hydroxyl absorbed on surface oxide, water molecules mainly absorbed on oxide surface, and oxygen in the titanium oxide $\left(\mathrm{TiO}_{2}\right)$ and/or zirconium oxide $\left(\mathrm{ZrO}_{2}\right)$ respectively, state 


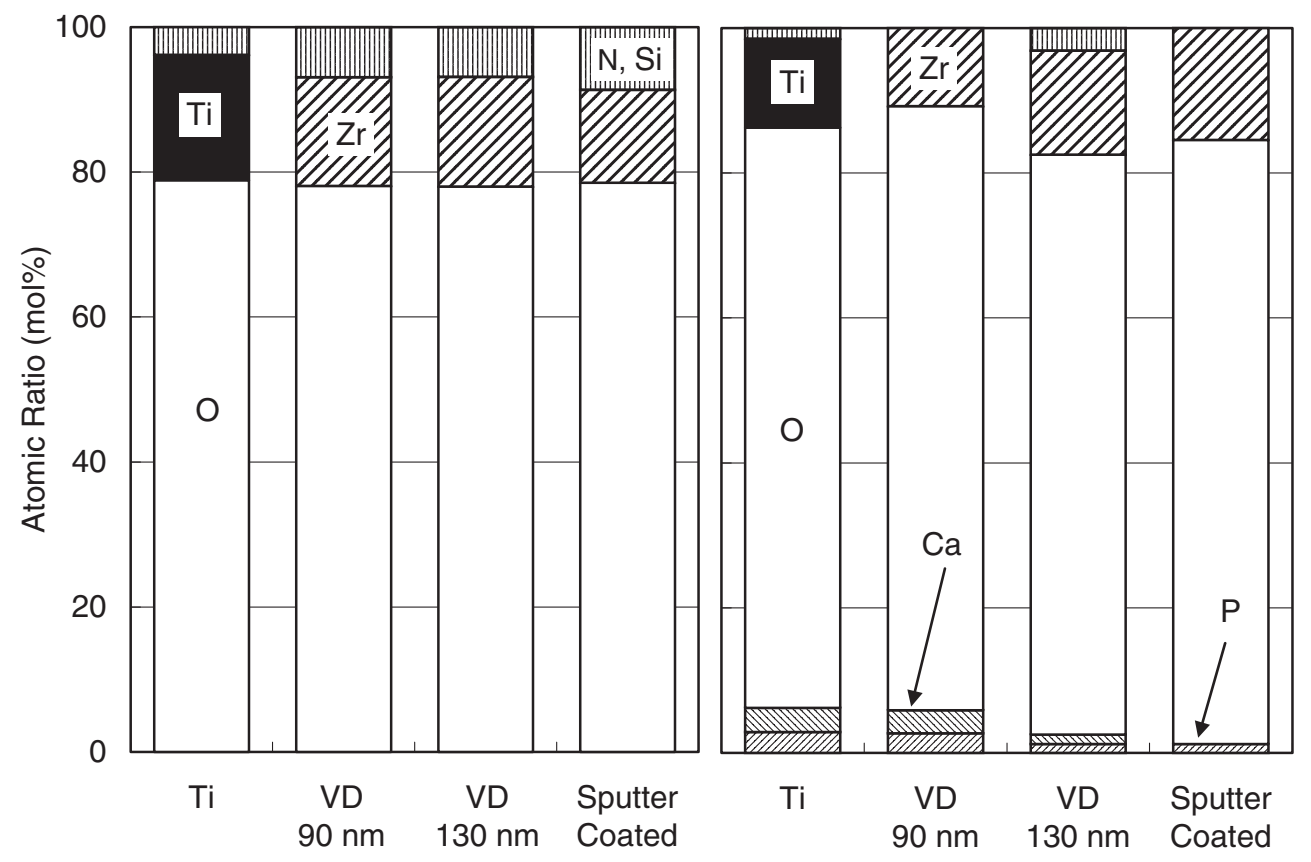

Fig. 5 Atomic ratio of specimens (left) before and (right) after immersion in Hanks' solution for $1 \mathrm{~d}$. Ti: Ti without Zr coating, VD: vapor deposited. $\mathrm{N}$ and $\mathrm{Si}$ were contamination atoms.
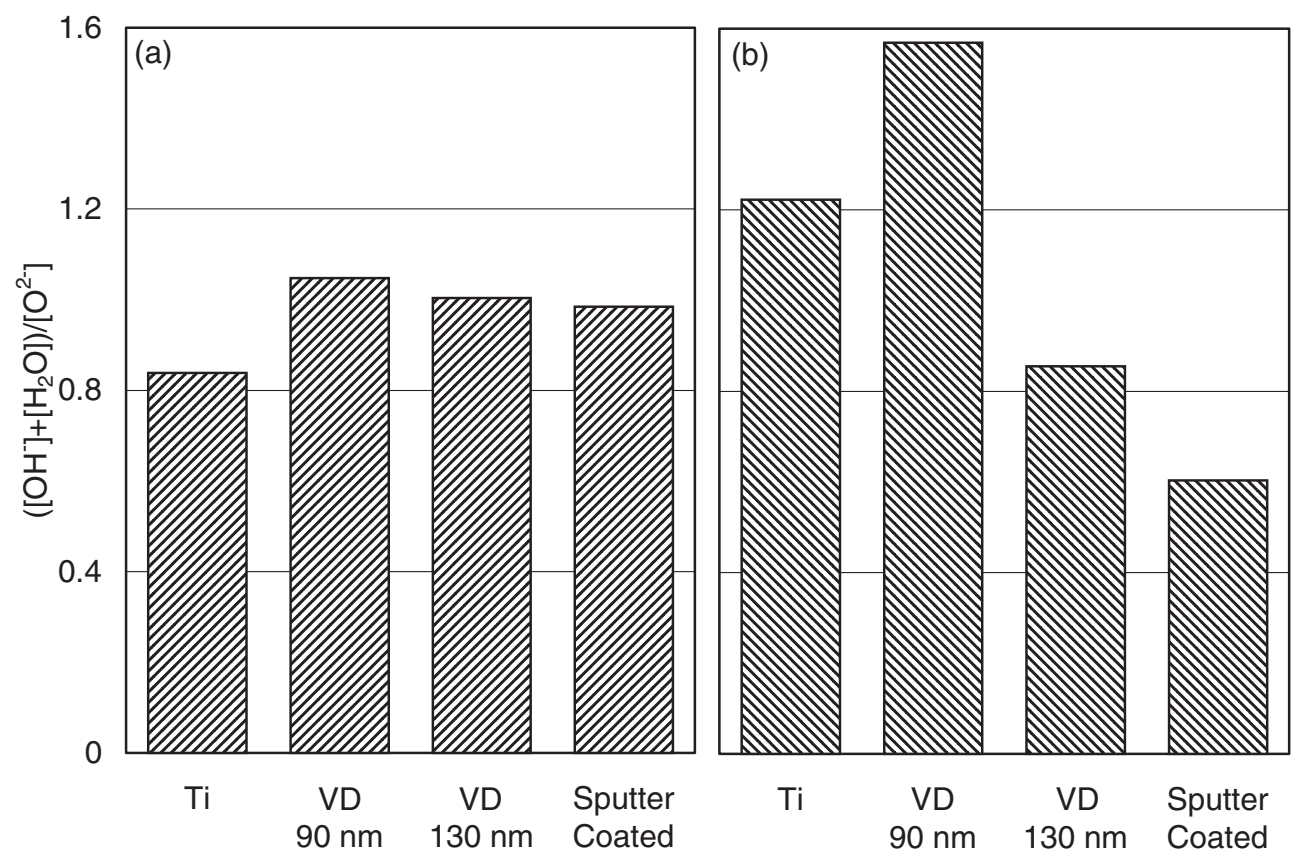

Fig. $6\left(\left[\mathrm{OH}^{-}\right]+\left[\mathrm{H}_{2} \mathrm{O}\right]\right) /\left[\mathrm{O}^{2-}\right]$ ratio of specimens (a) before and (b) after immersion in Hanks' solution for $1 \mathrm{~d}$. Ti: Ti without $\mathrm{Zr}$ coating, VD: vapor deposited.

analysis was carried out. Figure 6 indicates ratio of oxygen on the oxides surface $\left(\mathrm{OH}^{-}\right.$and $\left.\mathrm{H}_{2} \mathrm{O}\right)$ for that in the oxides $\left(\mathrm{O}^{2-}\right)$. From the surface analysis before Hanks' solution immersion, the specimens $\mathrm{Zr}$ vapor deposited and that $\mathrm{Zr}$ sputter-coated showed higher $\left(\left[\mathrm{OH}^{-}\right]+\left[\mathrm{H}_{2} \mathrm{O}\right]\right) /\left[\mathrm{O}^{2-}\right]$ value than $\mathrm{Ti}$ without $\mathrm{Zr}$. Comparing the $\left(\left[\mathrm{OH}^{-}\right]+\left[\mathrm{H}_{2} \mathrm{O}\right]\right) /\left[\mathrm{O}^{2-}\right]$ value before and after immersion, $\left(\left[\mathrm{OH}^{-}\right]+\left[\mathrm{H}_{2} \mathrm{O}\right]\right) /\left[\mathrm{O}^{2-}\right]$ value increased for the $\mathrm{Ti}$ specimen without $\mathrm{Zr}$ and the specimens $\mathrm{Zr}$ vapor deposited (90-nm thick), while the value decreased for the specimens $\mathrm{Zr}$ vapor deposited (130-nm thick) and Zr sputter-coated.

If once $\mathrm{Zr}$ is immersed into aqueous solution, following reactions might occur on the surface. ${ }^{3)}$

$$
\begin{aligned}
& \mathrm{Zr}_{2} \mathrm{O}_{3}+4 \mathrm{OH}^{-} \rightarrow 2 \mathrm{ZrO}(\mathrm{OH})_{2}+\mathrm{H}_{2} \mathrm{O}+2 \mathrm{e}^{-} \\
& 2 \mathrm{ZrO}(\mathrm{OH})_{2} \rightarrow \mathrm{ZrO}_{2}+2 \mathrm{H}_{2} \mathrm{O}
\end{aligned}
$$

According to these reactions, oxides film grows (which results in increasing of $\left.\left[\mathrm{O}^{2-}\right]\right)$ and the $\left(\left[\mathrm{OH}^{-}\right]+\right.$ $\left.\left[\mathrm{H}_{2} \mathrm{O}\right]\right) /\left[\mathrm{O}^{2-}\right]$ value will be decreased. Decreasing in the specimens $\mathrm{Zr}$ deposited (130-nm thick) and $\mathrm{Zr}$ sputter-coated 
can be understood by this description. On the other hand, the $\left(\left[\mathrm{OH}^{-}\right]+\left[\mathrm{H}_{2} \mathrm{O}\right]\right) /\left[\mathrm{O}^{2-}\right]$ value in the Ti specimen without $\mathrm{Zr}$ and the specimen $\mathrm{Zr}$ deposited (90-nm thick) was increased after immersion into Hanks' solution. It is considered due to calcium phosphate formation on these specimens. As shown in equations (1), hydroxyl group contributes to reactions for calcium phosphates. In the recent reports, it was also reported that there is a certain relation between quantity of hydroxyl and crystallization of calcium phosphate. ${ }^{6}$ )

\section{Conclusion}

On the surface of $\mathrm{Ti}$ without $\mathrm{Zr}$, particle precipitates were observed and they were analyzed as calcium phosphate. Calcium phosphate was also identified on the specimens with 90-nm thick $\mathrm{Zr}$ coated layer. On the other hand, the specimens with 130-nm thick $\mathrm{Zr}$ coated layer exhibited control of calcium phosphate precipitation on the surface. By the surface analysis of the specimens $\mathrm{Zr}$ sputter-coated, Ca was not identified. It was considered to form zirconium phosphate instead of calcium phosphate.

From above results, efficiency of vapor deposited coating of $\mathrm{Zr}$ on inhibiting calcium phosphate in the body fluid was confirmed. It will be more effective when the thickness of the coated layer becoming thicker. Within the XPS results in the present study, it was confirmed that the sputter coating which provides thicker layer can prevent calcium phosphate precipitation. It was suggested that this technique can be applied to orthopedic devices such as femoral, tibial and humeral nails and bone screws to avoid re-fracture of bone by calcium phosphate precipitation during removal operation.

\section{REFERENCES}

1) E. J. Kelly: Mod. Aspect Electrochem. 14 (1982) 319-424.

2) T. Hanawa and M. Ota: Biomaterials 12 (1991) 767-774.

3) T. Hanawa, O. Okuno and H. Hamanaka: J. Jpn. Inst. Metals. 56 (1992) 1168-1173.

4) M. Fini, A. Cigada, G. Rondelli, R. Chiesa, R. Giardino, G. Giavaresi, N. N. Aldini, P. Torricelli and B. Vicentini: Biomaterials 20 (1999) 1587-1594.

5) S. Ban and S. Maruno: Biomaterials 19 (1998) 1245-1253.

6) Y. Tanaka, E. Kobayashi, S. Hiromoto, K. Asami, H. Imai and T. Hanawa: J. Mater. Sci. Mater. Med. in press.

7) H. M. Kim, F. Miyaji, T. Kokubo and T. Nakamura: J. Biomed. Mater. Res. 32 (1996) 409-417.

8) C. Ohtsuki, H. Iida, S. Hayakawa and A. Osaka: J. Biomed. Mater. Res. 35 (1997) 39-47.

9) K. Hamada, M. Kon, H. Ukai, K. Murakami, Y. Miyamoto and K. Asaoka: Biomaterials 23 (2002) 2265-2272.

10) T. Hanawa, S. Kihara and K. Murakami: Characterization and Performance of Calcium Phosphate Coatings for Implants, ed. by E. Horowitz and J. E. Parr, (ASTM, Philadelphia, ASTM STP 1196), pp. 170-184.

11) T. Hanawa, K. Asami and K. Asaoka: Corros. Sci. 38 (1996) 15791594.

12) K. Asami: J. Electron Spectrosc. 9 (1976) 469-478.

13) K. Asami, K. Hashimoto and S. Shimodaira: Corros. Sci. 17 (1977) 713-723.

14) T. Hanawa, K. Asami and K. Asaoka: J. Biomed. Mater. Res. 40 (1998) 530-538. 